\title{
BANKING SERVICE ORIENTATION MODEL IN STRATEGIC HRM AND SYSTEM DYNAMICS PERSPECTIVE
}

\author{
Audia Junita ${ }^{1^{*}}$, Ferdinand Dehoutman Saragih ${ }^{2}$, Andreo Wahyudi Atmoko ${ }^{3}$ \\ ${ }^{1}$ Faculty of Economics and Business, Harapan University of Medan, Indonesia \\ ${ }^{2,3}$ Faculty of Administration Science, Indonesia University, Indonesia \\ *Corresponding author, email: audia.junita@yahoo.com
}

\begin{abstract}
This paper seeks to explore a model of banking service orientation in strategic human resource management and system dynamics perspective, theoretically. As a scientific effort to develop a study of strategic human resource management. So far, the relationship between elements in strategic human resource management perspective as a system is only analyzed linearly. This article is the result of a literature study. An analysis is done narratively, to answer research problems. Research finding in the form of banking service-orientation model in strategic human resource management and system dynamics perspective, that illustrates the interaction between marketing differentiation strategy, commitment-oriented human resource system, service-oriented role behavior and banking operational performance.
\end{abstract}

Keywords: Service orientation, strategic human resource management, banking, system dynamic.

\section{Introduction}

Service is a necessity in the banking industry. As a service-oriented business, banking not only offers products but also services. Service orientation is a strategy of competitive advantage in the banking industry (Coskun \& Frohlich, 1992). Banking services are directed not only to achieve a competitive advantage but also to the creation of value and innovation.

Competition in the banking industry has different characteristics from competition in other industrial sectors. At present the bank competes no longer in products and prices (interest rates), but more on improving various product characteristics, conventional transaction services (Sakapurnama \& Kusumastuti, 2013), promotions (Kusumastuti, 2007), number of branches, labor prices, distribution volume credit (Widyastuti \& Armanto, 2013) and the adoption of service-based differentiation strategies (Amin, Divandari, \& Haghani, 2015). At present, the product-based differentiation strategy is considered no longer sufficient for banks to be able to survive in the long run.

People-centered service is an important thing to study. Along with the expansion of the bank's business units, the readiness of infrastructure and internal resources to provide quality services also need to be prepared. The banking task is to manage internal resources to produce character resources, which are needed to differentiate companies from their competitors and have strategic value.

Research that examines aspects of banking services has been carried out, including in Indonesia, but generally focuses on service quality. Service quality in the banking industry is analyzed for its dimensions and its impact on both customer attitudes and behavior and banking performance itself (Assegaff, 2016; Darmayanti \& Cahyono, 2014; Hussein \& Hapsari, 2015; Jun \& Palacios, 2016; Lau, Cheung, Lam, \& Chu, 2013; Sharma \& Halvadia, 2015; Thaker, Khaliq, \& Thaker, 2016). Research that examines the mechanism of how service orientation in banking can affect business performance, involves any variables and how the dynamics of interactive relationships between variables involved in the system perspective are still very limited. Theoretical problems related to the complexity of the causal relationship between organizational strategy, human resource systems, role behavior, and organizational performance arise, that studies involving these variables have been carried out limited in the analysis of linear causal relationships. Even though the empirical study of the recursive relationship between the two is carried out, it still uses a linear approach (Chadwick, 2007; Katou, 2012; Piening, Baluch, \& Salge, 2013).

Therefore, this research is very important to do, given the performance of banks is determined by many determinant variables. In addition to analyze on the perspective of strategic human resource management, given that human assets act as strategic determinants in determining banking performance, an analysis is also carried out with a system dynamics perspective. System thinking approach which is the right way of thinking is carried out in complex and dynamic environmental conditions, looking at a phenomenon that is definitely influenced by many variables that are interdependent, interacting in non-linear relationships, as a system that influences each other to success (Maani \& Cavana, 2000; Senge, 1990). 
By basing the analysis on the literature review, this study will produce an output in the form of a theoretical model of how banking performance can be improved, from the perspective of strategic human resource management and system dynamics.

\section{Research Method}

This article is a relevant literature-based analytical study. Narrative analysis is used to answer research problems.

\section{Result and Discussion}

\section{Banking, Human and Service Orientation}

Banking and service are two things that cannot be separated from each other. Various researches at banking retail institutions, especially in Indonesia, prove that service is a major contributor to banking performance (Misbach, Surachman, \& Djumilah, 2013; Sakapurnama \& Kusumastuti, 2013; Toelle, 2006). Service is a bank strategy to meet market demands to be more humane (Coskun \& Frohlich, 1992).

High emphasis on efficiency aspects, often triggers banks to standardize work processes through dominant technology investments so that they often deny human aspects. Adoption of technology in banking is only one way to provide better service to consumers. In reality, the assumption that the banking business strategy has shifted to the cashless society has not been fully proven. Conventional transaction services are still maintained by the banking industry (Sakapurnama \& Kusumastuti, 2013). From a consumer perspective, banking is a business that is sensitive to personal aspects like other service business organizations.

Humans play an important role as assets that deserve to be taken into account (Morris, 2015; Pavkovic \& Marosevic, 2014; Santoso, 2011), determinants of efficiency, service quality and financial performance of the banking industry as well as technology. Human assets in banking are of strategic value for banking competitive advantage.

\section{Strategic Human Resource Management Perspective}

Strategic human resource management is part of strategic management science. Strategic human resource management assumes that organizational human resource management activities are of strategic value for the organization's competitive advantage, not merely technical activities. Various human resource management policies or activities interact with one another as a system called the human resource system. Harmony

Strategic human resource management has three perspectives, namely universalistic, contingency and configurational perspective (Delery \& Doty, 1996). The universalistic perspective assumes that some of the best practice management practices are universal, both applied in various organizations (Huselid, 1995). A universalistic perspective gets criticism from human resource management experts regarding human resource management practices which are considered "best practice". In fact, the practice of human resource management is very varied and if applied in different organizations, results in varying performance.

Contingency perspective assumes that management of organizational resources is a contingency, strongly influenced by internal and external factors of the organization (Jackson \& Schuler, 1995). Some internal environmental aspects that influence the organization's human resource management system are technology, structure, organizational size, stages of the organization's life cycle, work processes (Valle, Martin, Romero, \& Dolan, 2000) and business strategies (Delery \& Doty, 1996; Schuler \& Jackson, 1987a; Schuler \& Jackson, 1987b). While the external environmental aspects that affect the organization's human resource management system include the legal, social and political environment, trade unions, labor market conditions, industry characteristics and culture of a nation.

The third perspective is a configurational perspective, which adopts the assumption of 'fit' and 'equifinality' of the system (Delery \& Doty, 1996). Organizations that have an ideal configuration are capable of achieving the best horizontal and vertical alignment (Delery \& Doty, 1996). Vertical alignment (Delery \& Doty, 1996) means the same as external alignment (Baird \& Meshoulam, 1988), meaning human resource systems that are aligned with various dimensions of context and organizational design (Doty, Glick, \& Huber, 1993; Jackson \& Schuler, 1995), including organizational strategy. Different organizational strategies require different human resource systems. Whereas horizontal alignment (Delery \& Doty, 1996) has the same meaning as internal harmony (Baird \& Meshoulam, 1988), refers to internal consistency between various human resource management policies or practices within the organization in the organization's human resource system. The strength of human resource practices and policies as a system that has complementary characteristics exceeds the strength of the sum of the effects of in- 
dividual human resource practices and policies (Alewell \& Hansen, 2012). Inconsistencies between one practice and another in a human resource system will have a negative impact on the organization (Becker, Huselid, Pickus, \& Spratt, 1997). For example, a commitment-oriented human resource system includes elements (sub-systems) that one and the other elements of mutual support oriented to generate high commitment in the members of the organization. While the assumption of "equifinality" means that various combinations of elements of an ideal human resource system are directed towards the same goal, namely the effectiveness of the system (Doty et al., 1993). In general, the configurational perspective emphasizes testing the pattern of relationships between various independent variables on the dependent variable.

\section{Marketing Differentiation Strategy and Its Effect on Commitment-Oriented Human Resource System, Employee's Role Behavior of and Organizational Performance}

Strategies rely on unique activities. The strategy is an effort deliberately done by the organization to choose a series of activities that are different from those of competitors (Porter, 1996). Competitive strategy is a formula that is determined by a company that is able to provide an overview of the objectives to be achieved, and various policies needed to achieve goals (Porter, 1980). In general, strategic orientation provides an understanding to the organization how to facilitate interaction with a large number of diverse actors in the service system and to be the direction and standard of behavior for members of the organization (Karpen, Bove, Lukas, \& Zyphur, 2015).

Various types of business strategy organizational typologies exist in the study of strategic management (Nandakumar, Ghobadian, \& O'Regan, 2011). One of the dominant business strategy typologies used is Porter's generic strategy typology (Dess \& Davis, 1984) which is able to contribute to organizational profitability (Beard \& Dess, 1981).

Three generic competitive strategies include cost-leadership, differentiation, and focus (Porter, 1980, 1985). Cost leadership strategy, emphasizes competitive advantage in terms of product production costs. Consideration of economies of scale, cost minimization, technological expansion and access to raw materials are key in this strategy. Differentiation strategies, emphasizing on producing and marketing unique products or services based on buyer preferences, are usually balanced by high product prices. Focus strategy, oriented to customer segments, product lines, more specific marketing areas. The focus strategy includes efficiency focus and differentiation focus. The efficiency focus strategy is a strategy in certain segments and the differentiation focus where the company offers products that are unique to certain segments, which are not offered by competitors.

More specifically, Chung, Hsu, Tsai, Huang, and Tsai (2012), Kim and Lim (1988), and Miller (1986), classifies the variable "differentiation" competitive strategy as different from that proposed by (Porter, 1980, 1985), which includes differentiation of innovation and marketing differentiation. The dimensions of innovation differentiation are widely used by adaptive organizations, which are characterized by excellence in new products and new technologies, innovation, emphasis on research and development activities so that organizations can determine relatively high prices. While marketing differentiation is applied by organizations that offer attractive packages, good service, strategic location, product reliability, and good service. These organizations have the advantage of being marketers, spending a lot of money on advertising, sales, promotion, and distribution, but they rarely issue new products. Innovation differentiation strategies have the same meaning as product innovation strategies and marketing differentiation strategies meaning the same as quality improvement strategies (Huang, 2001).

Regarding service orientation in the banking industry, differentiation strategies are considered to be the right alternative strategic choices. Service is the main strategic orientation for banks. Because the types of products offered by banks are relatively the same as each other, banks are no longer competing in the interest rate. They compete in a refinement of various product characteristics and services and promotions (Kusumastuti, 2007). The product innovation-oriented differentiation strategy is considered no longer able to maintain the interests of the bank in the long run (Amin et al., 2015). Research shows that service orientation has a significant positive effect on dynamic capabilities and organizational performance (Wilden \& Gudergan, 2017). Organizations are better able to capture business opportunities better.

The choice of a particular organizational strategy also has an impact on the different ways in which the organization manages its human resources. Organizations with differentiation strategies require a commitment-oriented human resource system to execute these strategies, in order to contribute positively to organizational performance (Arthur, 1992, 1994; Nishii, Lepak, \& Schneider, 2008; Raduan \& Kumar, 2006; Sun, Aryee, \& Law, 2007). 
Marketing differentiation strategies are also significant to foster high commitment in organizational members (Arthur, 1992, 1994; Nishii et al., 2008; Sun et al., 2007) and service-oriented role behavior (Sun et al., 2007), both directly or through commitmentoriented human resource systems and subsequently impact on organizational performance. Alignment between the characteristics of business strategies, human resource system and employee's role behavior can contribute to the achievement of maximum organizational performance (Schuler \& Jackson, 1987a).

\section{Commitment-Oriented Human Resources System and Its Effect on Marketing Differentiation Strategy, Employee's Role Behavior and Organizational Performance}

The meaning of the system in the human resource system is that human resource management practices consist of several elements of activity/ policy that are complementary to each other and function as "bundles" (Macduffie, 1995). Various individual human resource policies or practices have limited ability to produce competitive advantage, but in combination, they have a stronger ability to enable companies to realize competitive advantage (Becker et al., 1997; Becker \& Gerhart, 1996; Delery \& Doty, 1996; Barney, 1995).

The human resource system that is aligned with the marketing differentiation strategy is a commitment-oriented human resource system (Arthur, 1992, 1994; Nishii et al., 2008; Sun et al., 2007) as a mechanism to leverage the service -oriented employee's role behavior and organizational performance. Efforts to foster organizational commitment in workers are highly dependent on the choice of human resource management strategies.

Commitment-oriented human resource system is a management system that creates conditions for workers to have high involvement in the organization, identify themselves with the overall organizational goals, an effort to foster commitment in the worker through a psychological contract between workers and organizations, which is based on exchange of relational (Arthur, 1992; Ghazanfar, Chuanmin, Siddique, \& Bashir, 2012; Kwon, Bae, \& Lawler, 2010; Ogilvie, 1986; Uen, Chien, \& Yen 2009; Zaitouni, Sawalha, \& El Sharif, 2011). Some characteristics of a commitment-oriented human resource system are shown in Table 1.

The marketing differentiation strategy requires high flexibility for the organization to run the production process and use resources according to market demands, therefore the organization is required to design a commitment-oriented human resource system, which is considered able to condition the characteristics of human resources needed, including the ability and trained to doing various tasks, working in situations of high uncertainty, being able to be given authority regarding the completion of specific tasks (Arthur, 1992). Organizations also need to design long-term needs-oriented human resource planning, performance appraisal and compensation systems that are able to "bind" the compliance of organizational members to commit to the organization's strategic objectives.

Table 1

Characteristics of Commitment-Oriented Human Resource System

\begin{tabular}{|c|c|}
\hline Sub System & Characteristic \\
\hline HR Planning & $\begin{array}{l}\text { - Making strategic planning for the organization's human resource needs, creating the quantity and quality of } \\
\text { human resources } \\
\text { - Evaluating the potential of the organization's human resources both in quantity and quality }\end{array}$ \\
\hline Job Design and & - Job design oriented to work enrichment \\
\hline Staffing & - Recruit prospective workers who are skilled and able to work in teams \\
\hline $\begin{array}{l}\text { Participation and } \\
\text { Involvement }\end{array}$ & $\begin{array}{l}\text { - Given the opportunity to be involved in decision making } \\
\text { - } \\
\text { - Pirect communication between hierarchies } \\
\text { course of the production process within the organization } \\
\text { - Actively involved in submitting suggestions for improvement to the organization } \\
\text { - Regularly, sharing business information with workers }\end{array}$ \\
\hline Training and & - Extensive training opportunities \\
\hline Development & - Efforts to develop personal employees for the long-term \\
\hline Compensation & $\begin{array}{l}\text { - Giving high salaries } \\
\text { - Variable compensation to trigger performance } \\
\text { - Compensation based on performance and behavior }\end{array}$ \\
\hline Performance Appraisal & $\begin{array}{l}\text { - Performance appraisal is carried out objectively based on performance and behavior } \\
\text { - Assessment results are used for the long-term development policy of workers }\end{array}$ \\
\hline
\end{tabular}


The characteristics of human resource management system as organizational processes can also be feedback for organizational strategy formulations (Ginsberg \& Venkatraman, 1985; Wrigth \& Snell, 1998). Commitment-oriented human resource systems that have not been effective in generating service-oriented employee's role behavior and achieving maximum organizational performance will be a correction material for organizations to revise the characteristics of their marketing differentiation strategies.

\section{Service-Oriented Role Behavior and Its Effect on Organizational Performance, Marketing Differentiation Strategy and Commitment-Oriented Human Resource System}

Role behavior is defined as a series of repetitive actions of individuals that are interconnected with the repeated actions of other individuals, to achieve the desired results (Katz \& Kahn, 1978). In organizations, individual work behavior is measured in relation to its role in a particular job or position. A role includes one or more activities from the overall activity patterns that influence each other in producing organizational output.

Katz (1964) in Williams (1988) categorized role behavior into two categories, namely in-role behavior, and extra-role behavior. In-role behavior is the behaviors that are required in a formal work or part of the execution of duties and responsibilities for the role of a job. This form of behavior is labeled with task performance (Borman \& Motowidlo, 1997), in-role behavior performance (Piercy, Cravens, Lane, N., \& Vorhies, 2006) and service performance (Chuang \& Liao, 2010). Extra-role behavior is behavior outside of job requirements, which contributes positively to organizational performance, including behavior to help colleagues, efforts to redesign work processes to make them more efficient and better at serving customers. This behavior is termed various terms including organizational citizenship behavior (OCB) (Smith, Organ, \& Near, 1983), prosocial behavior (Brief \& Motowidlo, 1986), organizational spontaneity (George \& Brief, 1992), discretionary behavior (Macduffie, 1995), contextual performance (Borman \& Motowidlo, 1997), helping behavior (Chuang \& Liao, 2010), service-oriented OCB (Bettencourt, Gwinner, \& Meuter, 2001).

Service-oriented role behavior has a significant impact on organizational effectiveness (Harris, 2009; Podsakoff \& MacKenzie, 1997; Sun et al., 2007). The actual of employee's role behavior will also be feedback for the formulation of strategies and organizational human resource system (Wrigth \& Snell,
1998). Organizations with employees who behave less responsibly will be the basis for the organization to correct the quality of its marketing differentiation strategies and commitment-oriented human resource system that have been implemented so far.

\section{Banking Performance and Its Effect on Marketing Differentiation Strategy, Commitment -Oriented Human Resource System and Employee's Role Behavior}

Organizational performance is a multidimensional construct (Cameron, 1981). Data sources for measuring organizational performance also vary can be sourced from leaders, workers, customers and financial. There is no consensus regarding what is the best measure of organizational performance (Carton $\&$ Hofer, 2010). In general, the concept of organizational performance includes (1) the effectiveness of the task or the achievement of objectives including output, results, efficiency and so on; (2) appropriate organizational structures and processes include organizational characteristics, organizational member satisfaction, motivation, conflict resolution, communication channels and so on; (3) environmental adaptation includes flexibility for changes, acquisition of resources, long-term adaptation, survival of life (Kanter \& Brinkerhoff, 1981).

Performance measures according to Dyer \& Reeves (1995) in Wrigth, Gardner, and Moynihan (2003) consists of:

1. The outcome of workers, including attitudes and behavior of workers. Aggregation of individual worker outcomes will be a measure of organizational performance.

2. Organizational outcomes, including operational performance measures such as productivity, quality, efficiency, customer satisfaction

3. Financial/accounting outcomes, including actual financial performance such as costs, income, profitability.

4. Market-based outcomes, including the value of the company in the money market, especially the stock price and its variations.

5. Outcomes of human resources include the level of labor turnover.

The multi-dimensional nature of organizational performance variables is due to the determinants that raise the appearance of organizational performance also vary. Various theoretical and empirical studies confirm that banking performance is supported by service orientation as a strategic choice of the organization (Aryee, Walumbwa, Seidu, \& Otaye, 2012; Mehra, Joyal, \& Rhee, 2011; Siddiqi, 2013; Wilden \& Gudergan, 2017), human resource-oriented sys- 
tems commitment (Aryee et al., 2012; Seidu, 2012; Bartel, 2004; Karami, Sahebalzamani, \& Sarabi, 2015; Kasasbeh, Harada, \& Noor, 2017; Madanat \& Khasawneh, 2018; Mansour, Gara, \& Chiha, 2014), service-oriented role behavior (Aryee et al., 2012; Chuang \& Liao, 2010; Nishii et al., 2008; Sun et al., 2007; Wilches-Alzate, 2009; Yaghoubi, Salehi, \& Moloudi, 2011).

Similarly, in banking, the performance measures used are very varied. Public banking in Indonesia uses performance measurement indicators referring to Financial Services Authority Regulation Number 4/POJK.03/2016 (The Financial Services Authority, 2016) and Financial Services Authority Circular Letter Number 14/ SEOJK.03/2017 (The Financial Services Authority, 2017) concerning the Assessment of Commercial Banks' Soundness Level based on Risk Based Bank Rating Method. The Risk Based Bank Rating method has a scope of assessment of four factors, namely the risk profile, Good Corporate Governance (GCG), profitability (earnings) and capital (capital). Risk profile factors are measured by the ratio of Non-Performing Loans (NPL). Earnings factor uses the ratio of Return on Assets (ROA) and Net Interest Margin (NIM). Capital factor uses the Capital Adequacy Ratio (CAR). The factor of Good Corporate Governance uses the results of self-assessment. These performance evaluation indicators are generally used at the corporate banking level.

More specifically at the business unit level, bank performance is largely determined by the achievement of operational performance supported by marketers. Bank business unit level performance is generally measured by the number of sales of banking products, namely growth in savings and loan aspects. Therefore both are the main components of banking income based on "spread income". The growth of deposits and credit at the bank's branch office becomes an indicator of branch performance assessment which will then be translated into an increase in spread income in the overall banking financial performance (Bartel, 2004).

As a profit-oriented company, the achievement of organizational performance periodically becomes an important thing that is controlled by banking management. Theoretically, good organizational performance achievement will be a feedback for strategy formulations (Ginsberg \& Venkatraman, 1985; Wrigth \& Snell, 1998) and organizational human resource system (Wrigth \& Snell, 1998). High-performance organizations will also have workers with high job satisfaction which will then stimulate service-oriented role behavior productive efficiency (Podsakoff \& MacKenzie, 1997).

\section{System Dynamics Model of Banking Service Orientation in Strategic Human Resource Management Perspective}

The system dynamics model of banking services from the perspective of strategic human resource management is based on the philosophy of systems thinking, namely the way of looking at a problem as a system that includes elements of the system that are interrelated to one another as a whole, not from individual parts of the pattern (Senge, 1990; Soesilo, \& Karuniasa, 2014). System thinking is a discipline used to understand complexity and change (Maani \& Cavana, 2000). Complexity, dynamics, non-linearity, and feedback become characteristics of system dynamics (Soesilo \& Karuniasa, 2014). System dynamics output is a model, which represents a decision making structure, information used and the results generated (Wahyudi, 2018).

Banking service orientation model in the perspective of strategic human resource management is complex because it includes at least four elements, namely marketing differentiation strategy, commitment-oriented human resource system, service-oriented role behavior, and banking performance. The four elements interact with each other in the mechanism of continuous work, and exchange positions as inputs, processes, outputs, and feedback in a basic structure of a non-linear causal relationship. The mechanism of the action takes place continuously as time changes (dynamic) (Muhammadi \& Soesilo, 2001). Characteristic of organizational strategy, human resource system, role behavior of organizational members and organizational performance interactively (Junita, 2015, 2016).

Organizations with marketing differentiation strategies compete in unique service quality and marketing to meet market demands and needs. Market demands and needs vary, requiring organizations to reduce standardization, resulting in increased levels of uncertainty in carrying out the production process.

For this reason, organizations must be flexible enough to manage production systems and organizational resources. In this condition, workers are required to have the flexibility to use various skills and competencies to complete various service tasks (Arthur, 1992). A commitment-oriented human resource system is judged to be very suitable to be applied to organizations with a marketing differentiation strategy (Arthur, 1992, 1994; Nishii et al., 2008; Sun et al., 2007). A commitment-oriented human resource system is identified as a system capable of eliciting service-oriented role behaviors from organizational 
members (Clarke \& Hill, 2012; Junita, 2016; Nasurdin, Ling, \& Fun, 2011; Nishii et al., 2008; Riaz \& Mahmood, 2017; Sun et al., 2007), especially those in production. Similarly, organizational service orientation is a good predictor of the emergence of highinvolvement organizational members (Popli \& Rizvi, 2015). In banking, marketers and front-line officers play an important role. Furthermore, service-oriented role behavior will contribute significantly to the achievement of organizational performance both financially (Wrigth et al., 2003), perceptual market performance (Aryee et al., 2012; Chuang \& Liao, 2010) and consumer satisfaction (Liao \& Chuang, 2004).

Nonlinear relationships appear when organizational performance is a guideline for organizational strategy choices (Ginsberg \& Venkatraman, 1985; Lee \& Miller, 1999), organizational human resource system design (Ginsberg \& Venkatraman, 1985; Chadwick, 2007; Katou, 2012; Wrigth \& Haggerty, 2005) and the role behavior of organizational members (Schneider, Hanges, Smith, \& Salvaggio, 2003; Wrigth \& Snell, 1998). Banks that are able to achieve high performance will have sufficient capital to carry out marketing differentiation strategies, intensely on efforts to offer the best service to customers. Organizations that have a high commitment to the welfare of workers, will increase the ability of workers to generate profitability and execute organizational strategies (Lee \& Miller, 1999).

The capital is also needed to carry out various commitment-oriented human resource sys-tem activities to members of the organization. Human resource management practices that are able to leverage high levels of commitment in workers require relatively large investments for staffing activities, training and development, compensation, engagement programs and performance appraisal, but are identified as a system capable of generating psychological bonds between workers and organization, which is based on relational compliance and not merely transactional compliance (Uen et al., 2009). The results of the study (Schneider et al., 2003) also concluded that financial and market performance have a significant effect on the satisfaction of organizational members both of satisfaction because of the increase in compensation, incentives and reputation of the organization due to the increase in performance. Increased satisfaction will be reflected in the emergence of positive behavior from workers. Attitudes predispose to behavior. Therefore, attitudes can be used to predict behavior.

Commitment-oriented human resource systems contribute significantly to banking performance (Aryee et al., 2012; Bartel, 2004; Karami et al., 2015;
Madanat \& Khasawneh, 2018; Mansour et al., 2014; Seidu, 2012). As a system, a commitment-oriented human resource system consists of elements that synergize with each other to foster workers' commitment, in addition to achieving maximum organizational performance. The actual human resource system as an organizational process can be a feedback (input) for the formulation of organizational strategy (Ginsberg \& Venkatraman, 1985). A commitment-oriented human resource system is the basis for banks to determine the intensity level of marketing differentiation strategies.

Similarly, service-oriented role behavior. The characteristics of service-oriented role behavior in banking will be the basis for the choice of organizational strategies and human resource systems (Wrigth \& Snell, 1998). Banks that have employees with good service-oriented role behavior will be the basis for the organization to remain focused on marketing differentiation strategies (Popli \& Rizvi, 2015) and commitment-oriented human resource systems (Junita, 2016) because of the human resource strategy and system the right one is used to leverage the service-oriented role behavior that is expected by banks.

The relationship between marketing differentiation strategy, commitment-oriented human resource system, service-oriented role behavior and banking operational performance in the perspective of strategic human resource management and system dynamics, can be seen in Figure 1.

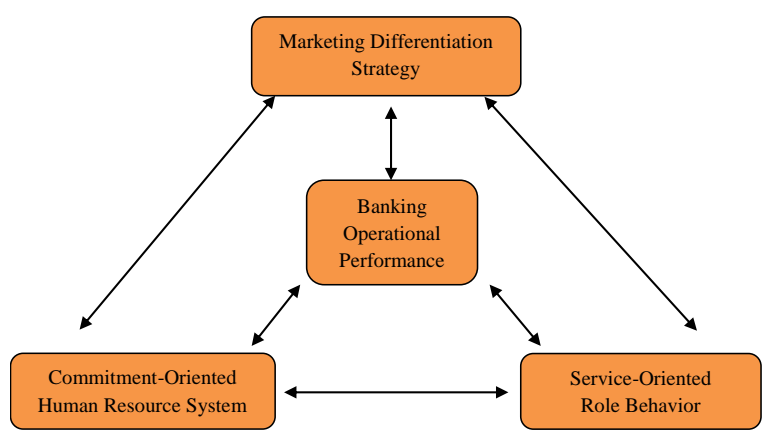

Figure 1. Model of banking service orientation in the perspective of strategic human resource management and system dynamics

\section{Conclusions and Implications}

Important services in the banking industry to differentiate themselves against competitors. Banking, as a service system, requires alignment between elements to achieve the desired output. Banking service orientation requires a commitment-oriented human resource system in the business process to 
leverage service-oriented role behavior from members of the organization as well as banking performance. The relationship between elements in the perspective of strategic human resource management includes marketing differentiation strategies, commitment-oriented human resource system, service-oriented role behavior and banking performance, integrated into a system model in an interactive (non-linear) relationship pattern, obtaining theoretical justification.

\section{Practical Implications}

An important implication of the results of this study is that humans in banking are a strategic assets for the bank's competitive advantage. Service orientation in banking is also an absolute matter. To be effective, service strategies need to be aligned with the design of a commitment-oriented human resource system to generate service-oriented role behavior from operational personnel. Service-oriented role behavior is a link that links business strategies and human resource system towards achieving banking performance. The achievement of the operational performance of the bank's business unit is largely determined by service-oriented role behavior of the operational personnel. The performance of the banking business unit is influenced by elements in the banking service orientation model in the perspective of strategic human resource management and system dynamics that interact dynamically with each other.

Analysis in strategic human resource management and system dynamics perspective in banking makes it possible to analyze non-linear interactions between complex subsystems (elements), so that the main leverage element can be found as well as the most optimal policy strategy to make the performance of model more optimal.

\section{Limitations of Research}

This research is limited to analysis in contingency perspective and configurational management of strategic human resources. The model of theoretical findings proposed, their use must be in accordance with the context analyzed, namely in service-oriented business organizations.

\section{Directions of Future Research}

The research needs to be further empirically validated to enrich the field of study of strategic human resource management, especially in the banking industry.

\section{References}

Alewell, D., \& Hansen, N. K. (2012). Human resource management systems - A structured review of research contributions and open questions. Industrielle Beziehungen, 19(2), 90-123.

Amin, F., Divandari, A., \& Haghani, M. (2015). Alignment of business strategies and human resource strategies in banking industry. European Online Journal of Natural and Social Sciences 2015, Special Issue on New Dimensions in Economics, Accounting and Management, 4(1), 1105-1121.

Arthur, J. B. (1992). The link between business strategy and industrial relations systems in American Steel Minimills. Industrial and Labor Relations Review, 45(3), 488-506.

-- (1994). Effects of human resource systems on manufacturing performance and turnover. The Academy of Management Journal, 37(3), 670 687.

Aryee, S., Walumbwa, F. O., Seidu, E. Y. M. \& Otaye, L. E. (2012). Impact of high-performance work systems on individual - and branch - level performance: Test of a multilevel model of intermediate linkages. Journal of Applied Psychology, 97(2), 287-300.

Assegaff, S. (2016). The effect of service quality to customer satisfaction by using internet banking service in Jambi. The Asian Journal of Technology Management, 9(1), 21-36.

Baird, L., \& Meshoulam, I. (1988). Managing two fits of strategic human resource management. The Academy of Management Review, 13(1), 116128.

Barney, J. B. (1995). Looking inside for competitive advantage. The Academy of Management Executive, 9(4), 49-61.

Bartel, A. P. (2004). Human resource management and organizational performance: Evidence from retail banking. Industrial and Labor Relations Review, 57(2), 181-203.

Beard, D. W., \& Dess, G. G. (1981). Corporate-level strategy, business-level strategy, and firm performance. The Academy of Management Journal, 24(4), 663-688.

Becker, B., \& Gerhart, B. (1996). The impact of human resource management on organizational performance: Progress and prospects. The Academy of Management Journal, 39 (4), 779-801.

Becker, B. E, Huselid, M. A., Pickus, P. S., \& Spratt, M. F. (1997). HR as a source of shareholder value: Research and recommendations. Human Resource Management, 36 (1), 39-47. 
Bettencourt, L. A., Gwinner, K. P., \& Meuter, M. L. (2001). A comparison of attitude, personality, and knowledge predictors of service-oriented organizational citizenship behaviors. Journal of Applied Psychology, 86(1), 29-41.

Borman, W. C., \& Motowidlo, S. J. (1997). Task performance and contextual performance: The meaning for personnel selection research. $\mathrm{Hu}$ man Performance, 10(2), 34-44.

Brief, A. P., \& Motowidlo, S. J. (1986). Prosocial organizational behaviors. The Academy of $\mathrm{Ma}$ nagement Review, 11(4), 710-725.

Cameron, K. (1981). Construct space and subjectivity problems in organizational effectiveness. Public Productivity Review, 5(2), 105-121.

Carton, R. B., \& Hofer, C. W. (2010). Organizational financial performance: Identifying and testing multiple dimensions. Academy of Entrepreneurship Journal, 16 (1), 1-23.

Chadwick, C. (2007). Examining non-linear relationships between human resource practices and manufacturing performance. Industrial and Labor Relations Review, 60(4), 499-521.

Chuang, C., \& Liao, H. (2010). Strategic human resource management in service context: Taking care of business by taking care of employees and customers. Personnel Psychology, 63(1), 153196.

Chung, Y. C., Hsu, Y. W., Tsai, S. C., Huang, H. L., \& Tsai, C. H. (2012). The correlation between business strategy, information technology, organizational culture, implementation of CRM, and business performance in a high-tech industry. South African Journal of Industrial Engineering, 23(2), 1-15.

Clarke, M. A., \& Hill, S. R. (2012). Promoting employee wellbeing and quality service outcomes: The role of hrm practices. Journal of Management \& Organization, 18(5), 702-713.

Coskun, A., \& Frohlich, C. L. (1992). Service: The competitive edge in banking. The Journal of Services Marketing, 6(1), 15-22.

Darmayanti, D., \& Cahyono, H. (2014). The influence of perceived service quality, attitudinal loyalty and corporate social responsibility on repeat patronage intention in retail banking in Indonesia. Journal of Business and Retail Management Research, 8(2), 16-23.

Delery, J. E., \& Doty, D. H. (1996). Modes of theorizing in strategic human resource management: Tests of universalistic, contingency and configurational performance predictions. The Academy of Management Journal, 39(4), 802-835.
Dess, G. G., \& Davis, P. S. (1984). Porter's (1980) generic strategies as determinants of strategic group membership and organizational performance. The Academy of Management Journal, 27(3), 467-488.

Doty, D. H., Glick, W. H., \& Huber, G. P. (1993). Fit, equifinality, and organizational effectiveness: A test of two configurational theories. The Academy of Management Journal, 36(6), 11961250.

George, J. M., \& Brief, A. P. (1992). Feeling gooddoing good: A conceptual analysis of the mood at work-organizational spontaneity relationship. Psychological Bulletin, 112 (2), 310-329.

Ghazanfar, F., Chuanmin, S., Siddique, M. \& Bashir, M. (2012). Exploring the relationship between human resource management practices and organizational commitment: Empirical evidence from the banking sector in China. Information Management and Business Review, 4(9), 502516.

Ginsberg, A., \& Venkatraman, N. (1985). Contingency perspectives of organizational strategy: A critical review of the empirical research. The Academy of Management Review, 10(3), 421434.

Harris, C. (2009). Strategic human resource management at the crossroads: Relationships among human resource capital, overlapping tenure behaviors, and performance. Dissertation. The University of Texas at Arlington.

Huang, T. (2001). The effects of linkage between business and human resource management strategies. Personnel Review, 30(2), 132-151.

Huselid, M. A. (1995). The impact of human resource management practices on turnover, productivity, and corporate financial performance. The Academy of Management Journal, 38(3), 635-672.

Hussein, A. S., \& Hapsari, R. (2015). Customers' perceptions of service quality dimensions in The Indonesian banking industry: An empirical study. Journal of Indonesian Economy and Business, 30(1), 17-29.

Jackson, S. E., \& Schuler, R. S. (1995). Understanding human resource management in the context of organizations and their environments. Annual Review of Psychology, 46, 237-264.

Johnson, D. E., Davis, S. B., \& Albright, T. L. (2009). Examining the relationship between employee attitudes and a firm's financial performance: A theoretical framework and causal investigation. Journal of Managerial Issues, 21(3), 367-382.

Jun, M., \& Palacios, S. (2016). Examining the key dimensions of mobile banking service quality: An exploratory study. The International Journal of Bank Marketing, 34(3), 307-326. 
Junita, A. (2015). Interdependence model of human resource system, organizational strategy and organizational performance. A paper presented in the conference: The 5th Annual International Conference Syiah Kuala University (AIC Unsyiah) 2015 in conjunction with the 8th International Conference of Chemical Engineering on Science and Applications (ChESA) 2015, Banda Aceh, Indonesia.

- (2016). The interactive relationship between human and organizational capital in strategic human resource management. International Research Journal of Business Studies, 9(1), 49-62.

Kanter, R. M., \& Brinkerhoff, D. (1981). Organizational performance: Recent developments in measurement. Annual Review of Sociology, 7, 321-349.

Karami, A., Sahebalzamani, S., \& Sarabi, B. (2015). The influence of hr practices on business strategy and firm performance: The case of banking industry in Iran. IUP Journal of Management Research, 14(1), 30-53.

Karpen, I. O., Bove, L. L., Lukas, B. A., \& Zyphur, M. J. (2015). Service-dominant orientation: Measurement and impact on performance outcomes. Journal of Retailing, 91 (1), 89-108.

Kasasbeh, E. A., Harada, Y., \& Noor, I. M. (2017). Developing a concetual model for the relationship between human resource management, ebusiness strategies and competitive Advantage. Journal of Internet Banking and Commerce, 22(1), 1-21.

Katou, A. A. (2012). Investigating reverse causality between human resource management policies and organizational performance in small firms. Management Research Review, 35(2), 134-156.

Katz, D., \& Kahn, R. L. (1978). The social psychology of organizations. New York: Wiley.

Kim, L., \& Lim, Y. (1988). Environment, generic strategies, and performance in A rapidly developing country: A taxonomic approach. The Academy of Management Journal, 31(4), 802-827.

Kusumastuti, S. Y. (2007). Derajat persaingan industri perbankan Indonesia: Setelah krisis ekonomi. A paper presented in the Economic Annual Academic Seminar IV collaboration with Post Graduate Faculty of Economic Science Indonesia University and Training and Education Centre Commerce Department Republic of Indonesia. Jakarta, Indonesia.

Kwon, K., Bae, J., \& Lawler, J. J. (2010). High commitment $\mathrm{hr}$ practices and top performers: Impacts on organizational commitment. Management International Review, 50(1), 57-80.
Lau, M. M., Cheung, R., Lam, A. Y. C., \& Chu, Y. T. (2013). Measuring service quality in the banking industry: A Hong Kong based study. Contemporary Management Research, 9(3), 263-282.

Lee, J., \& Miller, D. (1999). People matter: Commitment to employees, strategy and performance in Korean firms. Strategic Management Journal, 20(6), 579-593.

Liao, H., \& Chuang, A. (2004). A multilevel investigation of factors influencing employee service performance and customer outcomes. The Academy of Management Journal, 47(1), 41-58.

Maani, K. E., \& Cavana, R. Y. (2000). Systems thinking and modelling: Understanding change and complexity. New Zealand: Pearson Education New Zealand Limited.

Macduffie, J. P. (1995). Human resource bundles and manufacturing performance: Organizational logic and flexible production systems in the world auto industry. Industrial and Labor Relations Review, 48(2), 197-221.

Madanat, H. G., \& Khasawneh, A. S. (2018). Level of effectiveness of human resource management practices and its impact on employee's satisfaction in the banking sector of Jordan. Journal of Organizational Culture, Communications and Conflict, 22(1), 1-19.

Mansour, N., Gara, E., \& Chiha, G. (2014). Getting inside the black box: HR practices and firm performance within the Tunisian financial services industry. Personnel Review, 43(4), 490514.

Mehra, S., Joyal, A. D., \& Rhee, M. (2011). On adopting quality orientation as an operations philosophy to improve business performance in banking services. The International Journal of Quality \& Reliability Management, 28(9), 951968.

Miller, D. (1986). Configurations of strategy and structure: Towards a synthesis: Summary. Strategic Management Journal, 7(3), 233-249.

Misbach, I., Surachman, H., \& Djumilah, A. (2013). Islamic bank service quality and trust: Study on islamic bank in Makassar Indonesia. International Journal of Business and Management, $8(5), 48-61$.

Morris, C. (2015). An industry analysis of the Power of human capital for corporate performance: Evidence from South Africa. South African Journal of Economic and Management Sciences, 18(4), 486-499.

Muhammadi, A. E., \& Soesilo, B. (2001). Analisis sistem dinamis: Lingkungan hidup, sosial, ekonomi, manajemen. Jakarta: UMJ Press. 
Nandakumar, M. K., Ghobadian, A., \& O'Regan, N. (2011). Generic strategies and performanceEvidence from manufacturing firms. International Journal of Productivity and Performance Management, 60(3), 222-251.

Nasurdin, A. M., Ling, T. C., \& Fun, L. S. (2011). Service-oriented organizational credictive role of human resource management practices. International Journal of Arts \& Sciences, 4(9), 381394.

Nishii, L. H., Lepak, D. P., \& Schneider, B. (2008). Employee attributions of the "why" of hr practices: Their effects on employee attitudes and behaviors and customer satisfaction. Personnel Psychology, 61(3), 503-545.

Ogilvie, J. R. (1986). The role of human resource management practices in predicting organizational commitment. Group \& Organization Studies, 11(4), 335-359.

Pavkovic, A., \& Marosevic, K. (2014). Human capital in financial institutions. A paper presented in the Book of Proceedings. Varazdin Development and Entrepreneurship Agency (VADEA), 403-413.

Piening, E. P., Baluch, A. M., \& Salge, T. O. (2013). The relationship between employees' perceptions of human resource systems and organizational performance: Examining mediating mechanisms and temporal dynamics. Journal of Applied Psychology, 98(6), 926-947.

Piercy, N. F., Cravens, D. W., Lane, N., \& Vorhies, D. W. (2006). Driving organizational citizenship behaviors and salesperson in-role behavior performance: The role of management control and perceived organizational support. Academy of Marketing Science Journal, 34(2), 244-262.

Podsakoff, M., \& MacKenzie, S. B. (1997). Impact of organizational citizenship behavior on organizational performance: A review and suggestions for future research. Human Performance, 10, 133-155.

Popli, S., \& Rizvi, I. A. (2015). Exploring the relationship between service orientation, employee engagement and perceived leadership style: A study of managers in the private service sector organizations in India. The Journal of Services Marketing, 29(1), 59-70.

Porter, M. E. (1980). Competitive strategy: Techniques for analyzing industries and competitors. New York: The Free Press.

- (1985). Competitive advantage: Creating and sustaining superior performance. New York: The Free Press.
(1996). What is strategy? Harvard Business Review, November-December 1996.

Raduan, C. R., \& Kumar, N. (2006). The Influence of Organizational and Human Resource Management Strategies on Performance. Performance Improvement, 45(4), 18-48.

Riaz, A., \& Mahmood, H. Z. (2017). Cross-level relationship of implemented high performance work system and employee service outcomes: The mediating role of affective commitment. Pakistan Journal of Commerce and Social Sciences, 11(1), 351-373.

Sakapurnama, E., \& Kusumastuti, R. (2013). The development of online banking system in Indonesia, implication in human resources management strategy. Advances in Management \& Applied Economics, 3(2), 123-134.

Santoso, E. (2011). Intellectual capital in Indonesia: The influence on financial performance of banking industry. Published doctoral dissertation. University of Phoenix, USA.

Schneider, B., Hanges, P. J., Smith, D. B., \& Salvaggio, A. N. (2003). Which comes first: Employee attitudes or organizational financial and market performance? Journal of Applied Psychology, 88(5), 836-851.

Schuler, R. S., \& Jackson, S. E. (1987a). Linking competitive strategies with human resource management practices. The Academy of Management Executive, 1(3), 207-219.

- (1987b). Organizational strategy and organization level as determinants of human resource management practice HR. Human Resource Planning, 10(1), 1-17.

Seidu, Y. (2012). Human resource management and organizational performance: Evidence from the retail banking sector. Published doctoral dissertation. Aston University, United Kingdom

Senge, P. M. (1990). The fifth discipline: The art and practice of the learning organization. New York: Bantam Doubleday Dell Publishing Group, Inc.

Sharma, M. S., \& Halvadia, N. B. (2015). Measuring service quality of internet banking portal in India. Annals of Management Science, 4(2), 2951.

Siddiqi, M. A. (2013). Organizational service orientation influencing contact employee and customer responses. International Journal of Marketing \& Business Communication, 2(4), 30-40.

Smith, C. A., Organ, D. W., \& Near, J. P. (1983). Organizational citizenship behavior: Its nature and antecedents. Journal of Applied Psychology, $68,655-663$. 
Soesilo, B., \& Karuniasa, M. (2014). Pemodelan system dynamics untuk berbagai bidang ilmu pengetahuan, kebijakan pemerintah dan bisnis. Jakarta: Lembaga Penerbit Fakultas Ekonomi Universitas Indonesia.

Sun, L., Aryee, S., \& Law, K. S. (2007). High-performance human resource practices, citizenship behavior, and organizational performance: A relational perspective. The Academy of Management Journal, 50(3), 558-577.

Thaker, H. M. T., Khaliq, A., \& Thaker, M. A. M. T. (2016). Evaluating the service quality of Malaysian islamic banks: An importance-performance analysis Approach. International Journal of Business and Information, 11(3), 341-364.

The Financial Services Authority. (2016). Financial services authority regulation number 4/POJK/ Concerning the assessment of commercial bank soundness level.

- (2017). Financial services authority circular letter number 14/SEOJK.03/2017 concerning the assessment of commercial bank soundness level.

Toelle, S. (2006). The linkages among service quality attributes, customer value, customer satisfaction and customer loyalty in Indonesia retail banking. Published doctoral dissertation. Nova Southeastern University, USA.

Uen, J., Chien, M. S., \& Yen, Y. (2009). The mediating effects of psychological contracts on the relationship between human resource systems and role behaviors: A multilevel analysis. Journal of Business and Psychology, 24(2), 215-223.

Valle, R., Martin, F., Romero, P. M., \& Dolan, S. L. (2000). Business strategy, work processes and human resource training: Are they congruent? Journal of Organizational Behavior, 21(3), 283297.

Wahyudi, A. (2018). Dinamika knowing organization. Jakarta: FIA UI Press.
Widyastuti, R. S., \& Armanto, B. (2013). Kompetisi industri perbankan Indonesia. Buletin Ekonomi Moneter dan Perbankan, 15(4), 417-440.

Wilches-Alzate, G. (2009). The relationship between rewards and recognition, service-oriented organizational citizenship behaviour, and customer satisfaction. Published doctoral dissertation. University of Waterloo, Canada.

Wilden, R., \& Gudergan, S. (2017). Service-dominant orientation, dynamic capabilities and firm performance. Journal of Service Theory and Practice, 27 (4), 808-832.

Williams, L. J. (1988). Affective and nonaffective components of job satisfaction and organizational commitment as determinants of organizational citizenship and in-role behaviors. $\mathrm{Pu}-$ blished doctoral dissertation. Indiana University, USA.

Wrigth, P. M., Gardner, T. M., \& Moynihan, L. M. (2003). The impact of hr practices on the performance of business units. Human Resource Management Journal, 13(3), 21-36.

Wrigth, P. M., Haggerty, J. J. (2005). Missing variables in theries of strategic human resource management: Time, cause, and individuals. Management Revue, 16(2), 164-173.

Wrigth, P. M. \& Snell, S. A. (1998). Toward a unifying framework for exploring fit and flexibility in strategic human resource management. The Academy of Management Review, 23(4), 756-772.

Yaghoubi, N., Salehi, M., \& Moloudi, J. (2011). Improving service quality by using organizational citizenship behavior: Iranian evidence. Iranian Journal of Management Studies, 4(2), 79-97.

Zaitouni, M., Sawalha, N., \& El Sharif, A. (2011). The impact of human resource management practices on organizational commitment in the banking sector. International Journal of Business and Management, 6(6), 108-123. 